
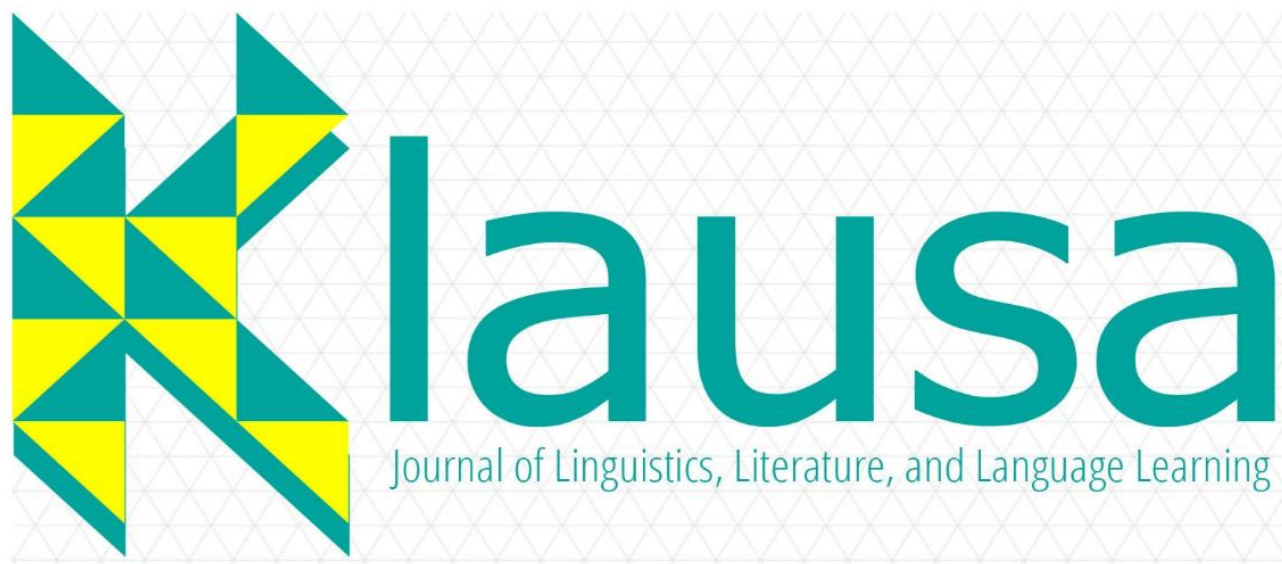

Journal of Linguistics, Literature, and Language Learning
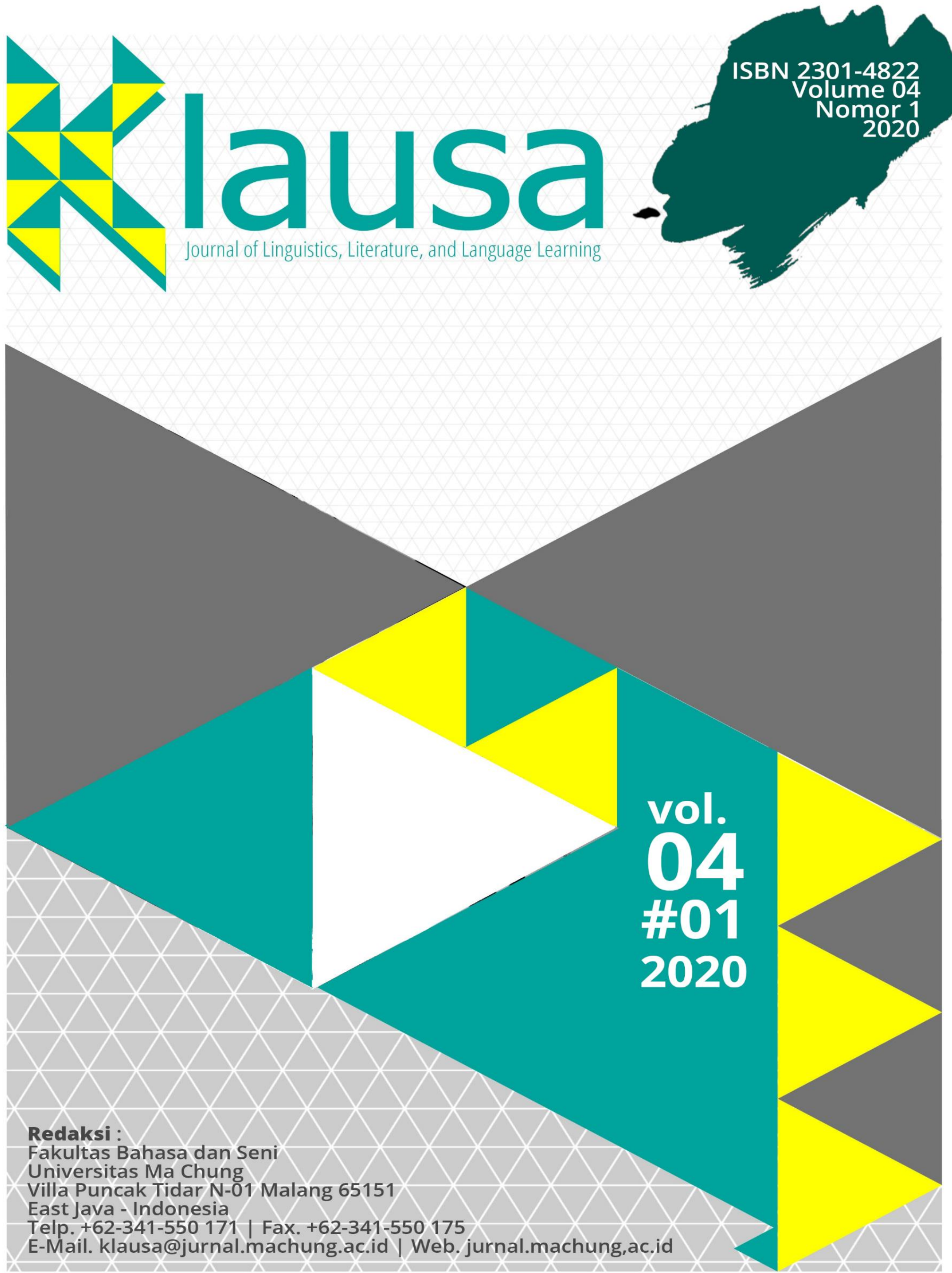
ISSN: $2301-4822(p)$

\section{$\Delta \Delta \| 5 \pi \bigcirc$ Kajian Linguistik, Pembelajaran Bahasa, dan Sastra}

\section{Editorial Team}

\section{Editor-in-Chief}

Journal Manager

Editors

Reviewers

Publisher

Address

Frequency
: Dr. Daniel Ginting

: Wawan Eko Yulianto, Ph.D.

: Prof. Dr. Patrisius I. Djiwandono

Lilis Lestari Wilujeng, M.Hum.

: F.X Dono Sunardi, M.A. Dhatu Sitaresmi, MTCSOL. Anggrah Diah Arlinda, MTCSOL. Yohanna Nirmalasari, S.Pd., M.Pd. Prof. A. Effendi Kadarisman, Ph.D. Sisilia Halim, Ph.D.

Dr. Mundi Rahayu

Dr. Ross Wood

Dr. Leticia Araceli Salas Serrano

: Faculty of Language and Arts

Universitsas Ma Chung

: The Faculty of Language and Arts

Ma Chung University

Villa Puncak Tidar N-01 (65151)

Malang, East Java, Indonesia

Email: jurnal.klausa@machung.ac.id

: Twice a year 


\section{CONTENTS}

FOREWORD

THE STRUCTURE OF COLLOCATION AND ITS TRANSLATION

STRUCTURES IN SUBTITLES OF KURZGESAGT

YOUTUBE CHANNEL

Cynthia Veronika

THE INSEPARABLE NARRATOLOGY AND GENRE IN DISNEY'S ALADDIN (2019): A STRUCTURALIST CRITICISM 11

Sandi Hamim

JUNIOR HIGH SCHOOL PERCEPTION OF COOPERATIVE

GROUP WORK

Puspita Nugraha Wibisono

THE INTEGRATION OF ISLAMIC VALUES IN THE

DEVELOPMENT OF LISTENING COURSE MATERIALS

Mazroatul Ishlahiyah, Mira Shartika

POLA ARGUMEN MAHASISWA JURUSAN PENDIDIKAN BAHASA

MANDARIN

Yohanna Nirmalasari 
ii | DOI: 10.33479/klausa.v4i01 


\title{
THE INTEGRATION OF ISLAMIC VALUES IN THE DEVELOPMENT OF LISTENING COURSE MATERIALS
}

\author{
Mazroatul Ishlahiyah ${ }^{1}$, Mira Shartika ${ }^{2}$ \\ ${ }^{1}$ UIN Maulana Malik Ibrahim Malang, mazroatul@uin-malang.ac.id, shartika@uin- \\ malang.ac.id
}

\begin{abstract}
Despite the fact that material development has been widely discussed and reported in the area of English Language Teaching, there is not much empirical evidence available so far that addresses material development in listening, especially in Indonesian context. To fill this gap, the writers examined the result of material development that includes the integration of Islamic values in some units of Nunan's Listen in 1 book. Employing Dick, Carey, \& Carey model of Research and Development design, the article exhibits the integration of Islamic values in the activities of warming up, main, and reflective, and game. The result of the study requires further research on material development, particularly on the creation of further material and audio developments.
\end{abstract}

Key Terms: Material Development, Listening, Integration of Islamic values

\section{INTRODUCTION}

In English learning, listening skill is considered as a non-productive skill which is put into priority for learning after speaking, writing, and reading because this ability is receptive. Basically the ability to hear is a passive process in which the listener only accepts the information conveyed by the speaker. However, this will be different when the listener is acquired to not only hear the listening material but is also asked to interpret the message intended by the speaker. In this case, listening skill is a complex and productive ability that students should become proficient in. Hichem (2013) argues that listening ability is a complex concept which is difficult to analyze. In fact, listening skill is not as simple and insignificant as ones previously thought.

Andrade (2006) contends that listening is one of two language skills used when communicating verbally, besides speaking. In addition, Huei-Chun (1998) in Ulum (2015) argues that listening skill is a "speech recognition", "perception of utterance", "comprehension of utterance", and "comprehension of spoken utterance". Consequently, listening can be considered as a very active process, in which listening is not only dealt with what is currently heard, but is also combined with other information that is formerly obtained. Hence, through this active process, students can create meaning by incorporating what is heard with the data or experience in students' minds (Helgesen, 2003).

Therefore, as an active learning process, listening can be divided into five stages, namely listening (receiving information), understanding (learning), remembering, evaluating (giving 
assessments/assumptions), and giving responses (answering) (Tyagi, 2013). If learners can successfully implement all stages in their listening practice, then they not only get new information but also recollect their prior knowledge.

However, because of the perception that has been ingested for decades in the language learners' minds, even in the minds of most researchers, that listening is a passive language learning ability, research in this field is scarce. Consequently, listening teaching material is also rather difficult to find. Additionally, most available teaching materials are outdated. Not to mention the unavailability of audio that should accompany the teaching material. Moreover, for learning materials with religious backgrounds such as in Islamic universities, the available teaching materials are often not in alignment with Islamic values which are the basis for students' character building. It is caused by the difference between Islamic culture and western culture. Consequently, in delivering materials, lecturers should be more careful and occasionally provide supplementary materials that are applicable with Islamic values.

This study was undertaken in one of Islamic universities in Malang, East Java, Indonesia. In the English Department in said university, literal listening is a compulsory course for the second semester students aiming at up skilling their first level of listening skill. At the second and third semester, students are required to take interpretive and critical listening course respectively. The literal listening course focuses on understanding the content, the rhetorical aspects, and the language features of various literal monologues and dialogues. For several years, Listen In 1 book written by David Nunan has been used as the pivotal reference for the course, considering its literal tasks and daily conversations. However, this book needs to be reinvestigated in accordance with Islamic values. Therefore, this research was aimed at investigating the integration of Islamic values to listening materials used in literal listening class.

\section{Listening Skill}

Listening is a complex ability that must be acquired by language learners because it builds several skills ranging from giving verbal and nonverbal responses. To have better understanding on listening skills, it is significant to identify the listening process from psychological point of views. According to Brown (2008), all information heard by the human ear will be captured by sensory memory. The information received will be sent to short-term memory or working memory, which will be forgotten if not trained. Through exercises that can be done either through elaborative exercises or memorizing, information can be sent through long-term memory to be retained in longer memories. In fact, there are five steps in processing listening, namely sensory memory, attention, short-term memory, exercise, and long-term memory. These five processes also go hand in hand with the theory put forward by Klatzky (1980).

Listening process takes place in 5 stages namely the stages of information registration, pattern recognition, registration information, training, and preservation of information (Klatzky, 1980). Two models of the listening process suggest the importance of attention (pattern recognition) and training. This implies that in teaching listening students need to be involved in listening activities that require their full attention. In addition, opportunities must be given to 
students to listen to the material repeatedly so that they can recognize the voice being spoken and the message conveyed in the listening materials.

Based on the cognitive model of language processing, there are two processes in listening ability: the bottom-up process and the top-down process (Anderson \& Lynch, 1988; Brown, 2006). Anderson \& Lynch (1988) state that the bottom-up process regards the listener as the recorder, while the top-down process considers the listener as the model builder. The first process shows that the listener receives and stores messages that are heard in the same way as tape-recorders, while the second process has a more active role in which the listener has to interpret the message being listened to. Nunan (1991) also suggests that the bottom-up process refers to the idea that the listener divides the flow of sound into its constituent voices, connects them to form words, then becomes chains of words which are then arranged to form clauses and sentences, and so on. This processing model assumes that listening is the process of decoding sound in a linear fashion, from the smallest meaningful units to complex texts (Nunan, 2002). Thus, this process refers to understanding the language that enters the sequential steps of sound, into words, into grammatical relationships and lexical meanings, and so on (Morley, 1991).

Meanwhile, top-down process allows listeners to bring knowledge outside the text to the task of interpreting and understanding the text itself. This process implies the important point that "meaning does not exist exclusively in words" in oral messages (Nunan, 1991). Therefore, Brown (2006) argues that one very important idea for teaching listening skill is that the listening class should utilize students' initial knowledge to improve their listening comprehension. Consequently, listening is an active process of constructing (or reconstructing) the original meaning of the speaker using incoming sound as a guide (Nunan, 2002).

However, listening ability is not only mastered by going through the bottom-up and the top-down process. Successful listeners are those who can take advantage of both bottom-up and top-down knowledge, as well as combine out-of-head knowledge with those inside the head. By undergoing all processes, the listener is considered as an active player in developing oral texts and using various strategies in reconstructing messages. In other words, successful listening acquisition involves the integration of information coded in one's own message with wider world knowledge (Nunan, 1991). Chang \& Read (2007) assert that in the process of listening, the listener uses two sources of information; one is systematic or linguistic information, and the other is schematic or non-linguistic information. Systemic knowledge involves phonology, lexis, syntax, semantics, and pragmatics, while schematic knowledge consists of relevant knowledge about individual topics, memories, and experiences.

In short, according to the theories of the listening process, listening will be done effectively if attention is given to the information being heard. To be remembered longer, that information needs to be trained with all the possibilities of meaning (for example, memorization and instruction). Thus, prior knowledge and the text to be used play a critical role in helping listeners to understand the information being heard. Some of the effective ways to obtain successful listening acquisition are through clear instructions in listening tasks, varied materials, and the use of diverse media. 


\section{Instructions, Materials, and Media in Listening Class}

The aforementioned theoretical views of the listening process have pedagogical implications for listening instruction. According to Morley (1991), the instruction procedure for understanding listening tasks can be divided into at least three types, involving listening as the main focus, listening to repeat, and listening to understand. Listening as the main focus presents two things, which cover initial attention to listening comprehension and delay in oral production. Listening to repeat, also referred to as imitating and memorizing, appears to be the main model of listening instruction in audio-language methodology where students are generally asked to listen, to be able to hear a model, and to reproduce it.

Listening instruction, conversely, aims to help students to understand the meaning of spoken language in various situations. This means that listening is seen as a separate skill, understanding meaning as a function of communicative language (Morley, 1991). The success of teaching listening is determined by a number of factors, one of which is the type of material.

Harmer (2007) classifies listening materials into extensive and intensive. Extensive listening is done outside the classroom. Therefore, any materials available outside the classroom, for example radio, TV, laptop, Internet, and so on, can be widely used to listening practice. Some of the advantages of extensive listening material are that students can use it based on their preferences and they can use as much material as they want (Harmer, 2007). Meanwhile, intensive listening materials, for example cassettes, CDs, or hard disks, are already available in classrooms or language laboratories. These materials may contain various types of texts (for example, stories, news, and academic texts) and modes of presentation, for example unscripted or natural discourse and written or prepared material. In intensive listening, students usually listen to the material at the same time and, if students do not use headsets, the sound quality may not be the same for all students.

Another factor that contributes to the success of listening acquisition is the media used to present listening material. The media can come from campus facilities such as the language laboratory. In addition, students can also use the existing media, such as Internet podcasts, YouTube and many others. However, for successful listening acquisition, teachers should prepare students for communicative listening activities where they can listen to understand messages and use these messages for both academic and communication purposes (Morley, 1991).

\section{Integration of Islamic Values in Listening Course}

All universities in Indonesia have taken a part to be responsible for their students' outcome. The institutions are also responsible for preparing students with pragmatic skills and knowledge for their future carrier as well as shaping the students' characters. In order to prepare the students to have Islamic integrity, the Islamic University in which this research took place has taken the basic concept of its education and offered Islamic values in the classroom. Madkur \& Albantani (2017) argue that instilling Islamic values in foreign language classroom in Indonesian context can be applied in curriculum, learning materials and instructional activities. However, since this 
research developed materials in listening class, the researchers only focused on developing learning materials and instructional activities.

Furthermore, in developing learning materials, a number of things can be done. Rohmah (2012) avers to add Islamic messages in learning materials. The substances are included in two ways: 1) directly mentioning Islamic topics like "How to do wudhu", "Muslim to Muslim" and so forth, or 2) incorporating the Islamic messages in the materials indirectly through pictures, names, building, language activities, messages, etc.

Other alternative of instilling Islamic values in the classroom is using value-based authentic materials (Madkur \& Albantani, 2017). Today it is easy to use authentic materials from newspapers, TV programs, menus, magazines, the internet (free access website containing a number of Islamic stories, movies, songs, brochures, comics, literature (novels, poems and short stories), and many others. Hence, integrating Islamic values in listening materials can be started from creating students' worksheets, such as the usage of picture, name, and language activities until using authentic materials.

In addition, Khamdan (2008) opines that the integration of Islamic values in instructional activities can be done in four ways i.e. (1) performing code mixing and code-switching between English and the Islamic expressions based on the situational context; (2) relating the topic discussed to the relevant Islamic teaching, which is done either by quoting the verses of Al-Qur'an and/or Al-Hadith, or by explaining the relevant Islamic teaching; (3) using the Islamic names for persons like Ahmad instead of John, Mecca instead of New York, or Eid al Fitr instead of Halloween in making examples in the sentences or conversation; (4) giving students assignment to write or find certain text related to Islamic values relevant to the topic being discussed.

The integration can be implemented through (1) accommodating the character values within the lesson, (2) instilling character values in every learning activity, (3) delivering the character values through teaching method used, and (4) planting and practicing character education values through everyday life (Albantani, 2016). Considering that listening course is full of instructions, there are various ways and instructions that can be used to promote and build Islamic values in listening course.

\section{RESEARCH METHOD}

\section{Research Design}

The design of this research is research and development (educational research and development) whose concept was introduced by Borg \& Gall (1983). According to Gall, Gall, \& Borg (2003), this research model is carried out in a cyclic form, where the products resulted from this cycle would be tested several times to find out whether the product is effective to replace the previous product. If in the testing process several errors are found, the product can be revised to produce a reliable final product. The testing process carried out several times is called the educational cycle (Borg \& Gall, 1983). Sukmadinata (2005) simplifies the cycle into several phases namely exploration, development, product trials, and implementation of the final product. 


\section{Research Subjects and Locations}

This research was carried out in the Department of English Literature in one of the Islamic universities in Malang. The subjects of this study were third semester students who passed Literal Listening course, so they were familiar with the course's materials. The course is a compulsory subject for second semester students. The purpose of this course is to introduce students to the ability to hear, to understand basic English conversations, and to understand the content, the rhetorical aspects, and the language features of various texts literally.

\section{Product Development Model}

As previously mentioned, the product or teaching material that was developed would go through several important phases, as asserted by Dick, Carey, \& Carey (2001), who divided the phases into ten detailed phases, namely information gathering, planning, initial product development, initial testing, product revision, further testing, product revision continued, final trials, final product revisions, and dissemination and implementation.

However, taking into account the limited time for conducting the research, the writers decided to use the Dick, Carey, \& Carey (2001) model in combination with the Sukmadinata (2005) model. This combination, which involved the modification of some chapters and activities, was then adapted to a few stages, namely information gathering (need analysis), product development, validation from experts, initial revisions, limited trials, second and final revisions, and dissemination and implementation. In addition, the researchers would not develop all of the materials but only a few materials that are irrelevant with Islamic values and outdated.

In fact, because the course is compulsory for second semester students and the subjects were third semester students who passed Literal Listening course, the researchers had a limitation to disseminate and implement the developed materials. The researchers only had limited trials for some students and created final revisions. Moreover, the developed materials will be disseminated and implemented for new students in the next academic year as supplementary materials or worksheets for the Literal Listening course, accompanying and substituting some chapters in the Listen In 1 book.

\section{Research Procedures}

At the research implementation stage, information gathering includes a review of the Literal Listening teaching materials that have been long used, namely the Listen in 1 book written by Nunan and published in 2003, as well as the syllabus of Literal Listening course. The book and syllabus consist of basic listening topics that do not include integration of Islamic values. In addition, some topics in the book and syllabus are less relevant to current conditions because the book was published sixteen years ago. The irrelevant topics are chosen for integrating the Islamic values and the chosen materials are adjusted with current situation and development of technology.

In the third stage, the research team asked for review from experts to validate the proposed teaching material. The experts consisted of several lecturers who are experienced in teaching Literal Listening course as well as several lecturers who have adequate knowledge about the integration of English teaching materials with Islamic values. 
The next stage was filled with material revisions based on the evaluation from the experts, which was based on the applicable curriculum, the appropriateness of instructions and activities, activity assessments, illustrations in books, and so on. Furthermore, the experts also validated the book based on several things which included the content of the teaching material, the language used, the activities and assignments listed in the teaching material, as well as the design of the teaching material.

After completing the revision, the product was tested on a limited basis. Third semester students who previously passed Literal Listening course were invited to test the teaching material. Once again, taking time constraints into account, not all chapters were tested. Some chapters that were considered representative were tried out. The trial results determined the product's final revision. The dissemination and implementation phases would follow afterward, when the materials were considered ready to use as supplementary materials or worksheets for the Literal Listening course, accompanying and substituting some chapters in the Listen In 1 book.

\section{FINDINGS AND DISCUSSION}

\section{Needs Analysis}

In exploring information related to the needs, opinions and expectations of students and lecturers, the researchers not only reviewed Listen in 1 book and Literal Listening's syllabus but also interviewed the lecturers. Those steps were done in order to provide information and analysis based on research, not just assumptions from researchers. In collecting the data, the researchers prepared interview questions, which are listed in the table below.

Table 4.1. Interview Questions for Needs Analysis

\begin{tabular}{|c|l|}
\hline No. & \multicolumn{1}{|c|}{ QUESTIONS } \\
\hline 1. & $\begin{array}{l}\text { In your opinion, is it necessary to teach listening with teaching materials that are } \\
\text { integrated with Islamic values? }\end{array}$ \\
\hline 2. & $\begin{array}{l}\text { In your opinion, what materials that are integrated with Islamic values and should } \\
\text { be included in the Listening materials? }\end{array}$ \\
\hline 3. & What kind of materials that are compatible with the integration of Islamic values? \\
\hline 4. & In your opinion, what kind of question that can be integrated with Islamic values? \\
\hline 5. & $\begin{array}{l}\text { What do you think about Listen in 1 book by David Nunan? Is the book still } \\
\text { relevant to use today? }\end{array}$ \\
\hline 6. & $\begin{array}{l}\text { Did you find some materials in Listen in 1 book that are not in accordance with the } \\
\text { university's mission to integrate Islamic values into teaching materials? }\end{array}$ \\
\hline
\end{tabular}

In needs analysis process, the researchers interviewed four lecturers of Literal Listening course. There were six questions to guide their opinions about the relevance of Listen in 1 book and integration of Islamic values in Literal Listening course. In fact, all of the lecturers agreed 
about integration of Islamic values in Literal Listening course since it is accordance with the vision and mission of the university. It can be concluded from the result of interview session.

Firstly, the researchers asked the following question. In your opinion, is it necessary to teach listening with teaching materials that are integrated with Islamic values? Depending on the vision and mission and objectives of the university, it is very necessary that the materials should be integrated with Islamic values. Also, the main purpose of our university is to produce graduates who have noble Islamic characteristics, the integration of Islamic values should be introduced as early as possible, This answer described that the materials should be developed based on the vision, mission and the objectives of the university in order to build students' character with high Islamic integrity.

Second question is about in your opinion, what materials that are integrated with Islamic values and should be included in the Listening materials? Lots of materials and topics that can be integrated with Islamic values, such as: Greetings, Celebration, Syahru Ramadhan, Daily Activities, etc. All lecturers gave some insights about some topics that could be included in new supplementary materials. In so doing, the students could get new information about Islamic values based on the topic being discussed.

However, to seek deeper for the lecturers' expectation of the new supplementary materials, the researchers also asked about what kind of materials that are compatible with the integration of Islamic values? The materials that can introduce Islamic culture other than only discussing foreign culture and combine both. Moreover, the acculturation of Islamic culture and foreign or western culture can also be included in the materials. According to the lecturers, the explanation about the differences of Islamic and foreign culture, and the assimilation of both cultures can give students new awareness of respecting different cultures.

Moreover, the researchers also asked the lecturers about the form of the assessment. In your opinion, what kind of questions that can be integrated with Islamic values? Many models of exercises can be applied in listening tasks, such as answering questions with short answers, multiple choices, filling in the blanks, games, songs, etc. The form of the exercises will influence the students in understanding the materials.

Meanwhile, the researchers also focused on the question about the lecturers' opinions of Listen in 1 book. What do you think about Listen in 1 book written by David Nunan? Is the book still relevant to use today? Not exactly. The book should be substituted with more recent references. Besides, some topics are repetitive. However, some other topics are still relevant with listening topics nowadays. Or maybe we can add some supplementary materials which can help us delivering the topics and increasing our students' interests.

Did you find some materials/topics in Listen in 1 book that are not in accordance with the university's mission on the integration of Islamic values? Some topics are irrelevant and not in accordance with Islamic values such as unit 1, unit 4, and unit 10. From this review, it could be concluded that the development of the existed reference was significant to improve the students' interests in acquiring listening skill especially in Literal Listening course. 
Moreover, the researchers also reviewed the syllabus of the course. Some topics were irrelevant with Islamic values and had similar objectives. Based on the review, there were five topics that would be developed. Those were unit 1 (Pleased to Meet You) and the objectives were greetings \& introduction, unit 3 (He's the One in the Blue Shirt) that was about physical description, unit 4 (Do You Like Rock?) that discussed music and preferences, unit 10 (How does It Work?) that explained about understanding instruction and following sequence of events, and unit 11 (I Usually Get up at Six) that explored daily activities.

\section{The Integration of Islamic Values in Literal Listening Materials}

In the process of developing literal listening material, the researchers only focused on topics that are irrelevant to Islamic values and are out of date. The researchers did not replace all materials but only developed the materials with some additional insights that contained values and materials that would attract students' interests. Each topic would be developed with the design of the materials covering the warming-up activities, the main activities, games, in focus which describes the reflection, and general knowledge containing Islamic values. This design was related to Veugelers \& Vedder (2003) who prefer to apply integrated approach by which the teachers will be able to both stimulate certain values and teaching language skills to better communicate on the values, and increase the active participation of students. In fact, the development would be described in each activity in all topics.

\section{A. Warming-up activities}

Warm-up activities are essential in English as a Foreign Language (EFL) classroom. Students may be tired or have other things on their minds and dive straight into a textbook or grammar explanation can be quite jarring. With a good warmer you can put your students into English mode, which include being attentive, interested in the lesson and are ready to participate in the activities. A warmer can also serve to review language from a previous lesson or prime the class for a new topic. Using warm up activities can also be one way to bring variation in class activity and to make the students curious of the topic to be discussed and focus their attention on the lesson, as well as to provide them with purpose and motivation (Eragamreddy, 2013).

In Literal Listening course, warming up activities are very important to introduce the topic that is going to be discussed. A warm-up stage is a preparatory stage which helps the students to feel relaxed and also sets a positive mood for learning (Rushidi, 2013). According to Robertson \& Acklam (2000) "warm up is a short activity for the beginning of lesson." Kay (1995) also claims that warm ups are different types of activities which help the students begin to think in English, review previously introduced materials and become interested in the lesson (as cited in Velandia, 2008). There are some ways in promoting warming up activities. As the research was focusing on integrating Islamic values, the warm up activities should contain the values, which were delivered in the messages, knowledge and activities.

First, Unit 1 promoted warming up activities by guessing what people would say when they met for the first time. Muslim people's greetings are varied, such as Assalamualaikum warrahmatullahi wabarakatuh, Hi, my name is Ahsan, Hello... I'm Aisyah, Waalaikumussalam 
warrahmatullahi wabarakatuh, Good morning, Pleased to meet you, etc. In addition, the students were also given some pictures to guess what greetings each person in the picture might say. Moreover, the picture also showed Muslim people's activities. The names used in warming up activities were also Muslim people's names like Ahsan, Aisyah, Ahmad, and so on.

The topic of Unit 3 was identifying people through physical description. In this case, some pictures which showed how Muslim people get dressed. The students were asked to look at the pictures and describe each person.

In Unit 4, which was about music and preferences, students were also asked to look at some photos of famous Muslim figures. They were then asked to guess who the people were and what type of music did each person sing or play. The pictures of Muslim performers also contained Islamic values, such as Islamic knowledge and culture.

In addition, in unit 10 and 11, warming up activities described the sequence of events in daily activities. In Unit 10 students were asked to explain about sequence, in this case how to do wudhu. Pictures containing the steps of doing wudhu were provided. Besides, in Unit 11, which was about daily activities, students were asked to tell about their activities in the dormitory. In this university, students are obliged to stay in the university's dormitory during their first year. The dormitory's daily activities included Shobaghul Lughoh, Tashih Qur'an, Ta 'lim, Arabic class, and so on.

Those warming up activities consisted of Islamic values by applying names, pictures and some valuable activities. It was in line with Rohmah (2012) who argue that Islamic messages should be added in learning materials in language teaching. The Islamic messages were included in the warm up activities by directly mentioning Islamic topics like "How to do wudhu" and indirectly incorporating the Islamic messages in the materials through pictures and names.

\section{B. Main activities}

In literal listening course, main activities are usually done after warming up activities. This activity focuses on the objectives of each topic. In this study, new materials did not substitute all units because the main focus of the research was on developing the learning objectives of each topic. The material development was done by creating worksheets which contained Islamic values, as supported by Rohmah (2012).

This design of Unit 1 was substituting western names with Muslim names like Aisyah, Siti, Omar, Hamad, Muhammad, Khalifa, Rasyid, Yousef, Aminah, Noor, Jamaluddin, Muhammad, Adam, etc. It was applied since the objectives of this unit was confirming people's name. Hence, the students not only learnt to confirm people's names but also to understand some of Muslim names. Besides, this unit also presented the activity of matching people's name with its proper meaning, for example Humaira (The nickname of Aisha (R.A)), Bilal (The name of the Prophet's muezzin), Habiba (Sweetheart, Darling), Abdullah (Allah's servant), etc. Those activities helped the students in learning how to confirm people's name and improving their Islamic knowledge.

In addition, in Unit 3 pictures were used to deliver the materials. The students should guess the name of the famous Muslim leaders. They were then asked to fill in the blanks related to the 
biography and the physical description of the leaders and number the pictures. Those activities were given in achieving the goal of this unit.

Meanwhile, in Unit 4 students were asked to listen to each conversation and number the CD Hasan and Alisya were talking about. They had to identify which one Hasan and Marsha like and dislike. However, main activities in this unit were not much developed because the other activities provided many activities that helped achieving the objectives of this unit's learning such as recognizing genre of music and listening to music.

Then, Unit 10 had two objectives which focused on understanding instructions and following sequence of events. In this unit, students were asked to listen to the audio and number the pictures according to the sequence they heard. They were asked to listen to the audio again and determine the time when Tayammum can be done. It was applied to give additional knowledge about the instruction in doing Tayammum. It was not only achieving this unit's objectives but also integrating Islamic values by promoting how to do Tayammum.

In Unit 11 there were two objectives to be fulfilled, including identifying times and events and understanding the schedule. When the learning objectives are achieved, the researchers did not do much material development because the materials and the instructions were still very suitable for students. They were asked to listen to the audio and number the times in the order they heard. In the audio, three people were describing their daily routines. Students were also asked to listen to the audio and fill in the blanks under event. The researchers further integrated Islamic value to the others, like warming-up activities, games and in focus.

Finally, not all the materials have the integration of Islamic values because the researchers had to consider achieving the objectives of every topic/unit and the limitation of the research. However, considering what Hidayati (2016) argues, that as the English material with Islamic content is still very limited, it is important for teachers to be creative. Although materials for other levels of education have not been suggested here, teachers can improvise their instruction based on the available resources. Therefore, the presenters developed the materials by considering the objectives, the topic and the level of the students. Moreover, all of the activities and the developed materials contained integration of Islamic values since they used the Islamic names for persons like Ahmad instead of John, places like Mecca, or events in making the example of sentences or conversation script (Khamdan, 2008).

\section{Games}

Game is one of the ways in improving the students' interest. It was in line with Mei \& YuJing (2000) who aver that games can increase the motivation of the students because they play as an alternative solution which encourages students to keep their interest on the lesson and continue working. Mora \& Gomez (2001) added that 'games promote socialization, group work, and the creation of values'. Games give students opportunities to practice the foreign language while practicing to work collaboratively. Thus, games create good atmosphere in the classroom and give positive impact at the learning outcomes.

In this research, games were included in the listening materials, for example in Unit 1

"Spelling Bee" game was used. Through this game, students were asked to spell some words 
correctly. In this research, students spelled some Islamic terms or Muslim people's names. In addition, in Unit 3 and 10 students were asked to identify some pictures. In Unit 3 the lifestyles of Jew, Hindi \& Muslim people and the way Muslim people dress were shown in pictures to students. They were then asked to match the pictures as well as to clarify their choices. In Unit $10 \mathrm{Wudhu}$ needs some water to clean up few parts of the body. Students were asked to circle the tool that can be used to take some water for wudhu and give brief explanation regarding their choices. Those activities were used to instill Islamic values in the class, which was related to Rohmah (2012) who opines to directly mention Islamic topics like "Tayammum, Wudhu, Muslim" and incorporate the Islamic messages in the materials indirectly through pictures, names, language activities, and so on. In addition, based on Khamdan's study (2008), in the instructional activities, the integration of the Islamic values was done by using the Islamic names for persons like Ahmad instead of John and places like Mecca.

However, in Unit 4 students were asked to do something different, which was listening to Maher Zain's song entitled Insha Allah and filling in the blanks in the song lyrics. This way was corresponded with the study done by Madkur \& Albantani (2017). They argue that incorporating Islamic values in the classroom can be done by using value-based authentic materials. The materials could be taken from the Internet (free access website containing a number of Islamic stories, movies, songs, brochures, comics, literature (novels, poems and short stories), and many others. Furthermore, in Unit 11 students were asked to work in pairs and make conversation about their daily routine. This strategy of Islamic value integration is in line with what has been elaborated by Madkur \& Albantani (2016), in which the integration can be implemented through instilling character values in every learning activity and planting or practicing character education values through everyday life.

\section{In Focus}

This part only focused on elaborating the topic of every unit. This section was a reflection of every material that had been discussed. Students could have discussions related to the topic. Thus, the integration of Islamic values could be developed further such as through cultural exposure, reflection on students' learning and everyday life. Khamdan (2008) contended that the integration of Islamic values can be applied by performing code mixing and code-switching between English and the Islamic expressions based on the situational context and by giving students assignment to write or find a kind of text related to the Islamic values relevant to the topic discussed. Finally, this part usually elaborated students' understanding by giving instruction to do some activities and assignments related to the topic.

\section{CONCLUSION}

This research developed supplementary material in Literal Listening course. The development was conducted with materials from Listen in 1 book by David Nunan. Five units were developed representing the integration of the materials with Islamic values. The developed materials were Unit 1 (Pleased to Meet You), Unit 3 (He's the One in the Blue Shirt), Unit 4 (Do You Like Rock), Unit 10 (How does It Work?), and Unit 11 (I Usually Get up at Six). The design 
of the materials presented the warming-up activities, the main activities, games, reflection, and general knowledge containing Islamic values. The appropriateness of the developed learning materials was shown in terms of content, instruction, and language.

Based on the conclusion above, the researchers propose two suggestions. Firstly, regarding the effectiveness of the material development, the supporting innovative audio can be developed for some activities that have not been accompanied with the relevant audio. The teachers can use some existing references or elaborate new audio by creating new conversations containing Islamic values.

Secondly, it is expected that the next researchers, who intend to carry out further research in the relation with the research findings, can continue this research by developing all the topics in the book.

\section{REFERENCES}

Albantani, A., M. (2016). Integrating character education values in language teaching: Why and how? The Fourth ELITE International Conference Proceeding. Jakarta: UIN Jakarta.

Anderson, A., \& Lynch, T. (1988). Listening. Oxford: Oxford University Press.

Andrade, M. E. A. D. (2006). Improving how listening skills are taught in the EFL classroom: Guidelines to producing better speakers of the English language (Bachelor's thesis).

Borg, W. R. \& Gall, M. D. (1983). Educational research: An introduction (4 ${ }^{\text {th }}$ ed.). New York: Longman.

Brown, B. L. (2008). The Information Processing Model of Memory.

Brown, S. (2006). Teaching listening. Cambridge: Cambridge University Press.

Chang, A. C. S., \& Read, J. (2007). Support for foreign language listeners: Its effectiveness and limitations. RELC journal, 38(3), 375-394.

Dick, W., Carey, L., \& Carey, J. O. (2001). The systematic design of instruction. Florida.

Eragamreddy, N. (2013). Teaching creative thinking skills. International Journal of English language \& translation studies, 1(2), 124-145.

Gall, M. D., Gall, J. P., \& Borg, W. R. (2003). Educational research: An introduction. Boston, M A: A \& B Publications.

Harmer, J. (2007). The practice of English language teaching. (4 $4^{\text {th }}$ ed.). Essex, UK: Pearson Education.

Helgesen, M. (2003). Listening in practical language teaching. Nunan, D. (ed.).

Hichem, B. (2013). An investigation on listening challenges facing EFL learners (Doctoral dissertation, MA Thesis. Mohamed Khider University of BISKRA: Algeria).Hidayati, T. (2016). English Language Teaching in Islamic Education in Indonesia: Challenges and Opportunities. Englisia, 3(2), 65-82.

Khamdan, N. (2008). The integration of teaching of English with the Islamic values at SMP Islam Al-Azhar 15 Cilacap. Unpublished Thesis. State Univesity of Malang.

Klatzky, R. (1980). Human memory: Structures and processes. San Francisco: W.H. Freeman \& Co. 
Madkur, A. \& Albantani, A., M. (2017). Instilling Islamic Values in Foreign Language Teaching: An Indonesian Context. 3rd International Conferences on Education in Muslim Society (ICEMS 2017) Jakarta: UIN Jakarta.

Mei, Y. Y., \& Yu-Jing, J. (2000). Using games in an EFL class for children. Daejin University. ELT Research Paper. Fall.

Mora, R. A., \& Gómez, M. C. L. (2001). Games in the classroom: More than just having fun. HOW journal, 8(1), 75-82.

Morley, J. (1991). Listening comprehension in second/foreign language instruction. Teaching English as a second or foreign language, 2, 81-106.

Nunan, D. (1991). Language teaching methodology: A textbook for teachers. New York: PrenticeHall.

Nunan, D. (2002). Listening in Language Learning. In Richards, J.C., \& Renandya, W.A. (Eds.), Methodology in Language teaching: An Anthology of Current Practice (pp. 238-241). Cambridge: Cambridge University Press.

Robertson, C., \& Acklam, R. (2000). Action Plan for Teachers a guide to teaching English. London, UK: BBC World Service.

Rohmah, Z. (2012). Incorporating Islamic messages in the English teaching in Indonesian context. International Journal of Social, Science, and Education, 2(2), pp. 157-165.

Rushidi, J. (2013). The Benefits and Downsides of Creative Methods of Teaching in an EFL Classroom: A Case Study Conducted at South East European University, TetovoMacedonia. Benefits, 4(20).

Sukmadinata, N. S. (2005). Metode penelitian pendidikan. Bandung: Program Pascasarjana UPI dan PT Remaja Rosdakarya.

Tyagi, B. (2013). Listening: An important skill and its various aspects. The Criterion An International Journal in English, 12, 1-8.

Ulum, Ö. G. (2015). Listening: The ignored skill in EFL context. Online Submission, 2(5), 72-76.

Veugelers, W. \& Vedder, P. (2003). Values in teaching. Teachers and Teaching: theory and practice, 9(4), pp. 377-389.

Velandia, R. (2008). The role of warming up activities in adolescent students' involvement during the English class. Profile Issues in TeachersProfessional Development, (10), 9-26.

58 | DOI: 10.33479/klausa.v4i01 